\title{
The Morphology of Trichodiscus elegans, Gen. et Sp. Nov. ${ }^{1}$
}

\author{
BY \\ E. J. WELSFORD, F.L.S. \\ Research Assistant, Department of Botany, University of Leeds.
}

CCURRENCE. In March, I9I0, whilst examining some Azolla caro. lina growing in a glass jar of rain-water in the greenhouse of the Royal Holloway College, I found a small green Alga which I was unable to identify. The plants were growing in small circular patches on the glass and also in a few cases on the Azolla, but in this situation they were exceedingly difficult to see.

The Azolla was bought in the previous November from Messrs. Ware and Sons, Limited, of Feltham, who had imported it from North Carolina, probably from Salem, and it is possible that the Alga was introduced from that district.

Methods. Glass cover-slips were suspended in water against the side of a jar, and in a few weeks were covered with young Algae. Some of the slips were examined daily, and the development of the plant was studied in this way in the living condition. Material was also fixed in different stages of development in Flemming's weak solution and in $4 \%$ formaldehyde. In the former case it was generally stained with haematoxylin or with brazilin, and mounted in Venice turpentine.

MoRPHOLOGY. The Alga forms small circular green patches about $\mathrm{I} \mathrm{mm}$. in diameter, and is firmly fixed to the substratum. It consists of a flat disc bearing numerous erect branches and long septate hairs. The disc is one cell thick and is formed of branched creeping filaments which cohere to form a pseudo-parenchymatous thallus, the peripheral branches of which are more or less free, and sometimes curve upwards. All the cells of the disc, with the exception of the rapidly growing free apices of the filaments, are capable of giving rise to one or two short erect branches; these branches are more freely developed on old than on young plants. Hairs are not very numerous, and are usually found towards the periphery of the thallus. They are often $300 \mu$ long, and

1 A short account of this work was read before Section $\mathrm{K}$ of the British Association, at the meeting held at Winnipeg in September, 1909, and was published in the report.

[Annals of Botany, Vol. XXVI. No. CI. January, Ig12.] 
consist of several cells; the basal ones contain chlorophyll, and the rest are colourless. The ordinary branches of the thallus arise as outgrowths immediately behind a septum. The hairs develop in a very similar way, but usually grow out from the middle of a lateral wall. The presence of protoplasm in every cell of the hair was clearly demonstrated in preparations stained with brazilin, and it seems probable that these hairs are really slightly modified branches.

The vegetative cells of the disc and branches contain a large parietal chloroplast with irregular lobes, a nucleus, and a pyrenoid.

REPRODUCTION. In young plants any cell is capable of producing zoospores, but as development proceeds a certain amount of differentiation takes place. The most common reproductive organs at this stage are large sporangia, which may be either terminal or intercalary, and which are always characterized by deep coloration. They generally occur in groups, and the various successive stages by which the contents of the sporangium divide into eight portions may often be found close together. The mature sporangium measures about $16 \times 12 \mu$, and contains eight gametes which are set free through a pore or pores in the wall. When first liberated each gamete measures about $3 \mu$ in length, but quickly becomes $6 \mu$, and shows a distinct eye-spot and two equal cilia; the zoospores soon fuse in pairs and come to rest. The interval of time between fusion and germination was not determined, but some of the stages of germination were studied.

The zygote at an early stage appears to be firmly fixed to the substratum ; a branch grows out from one end of it and is cut off by a cell-wall. As soon as this cell has developed into a short filament, another branch usually grows out from the opposite end of the zygote. Occasionally a zygote germinates at both ends simultaneously. The first-formed filaments grow rapidly, branch, and develop into the characteristic thallus. In many cases zygotes were found germinating so close to one another that their filaments combined together to form one plant or colony.

Sometimes the contents of the sporangium fail to form gametes, and while still within the cell-wall divide to form a filament of from 2 to 8 cells. The wall of the sporangium eventually ruptures, setting free the young plant. Occasionally cases were found in which the sporangium ruptured after the first division and liberated two non-motile daughter-cells which were capable of germination.

Besides these large sporangia, groups of smaller ones are found on poorly developed filaments. They measure about $6 \times 4 \mu$, and contain from 8 to 16 motile cells which are liberated through an opening with a definite lid, which, however, is quickly lost. Owing to their small size and rapid movement their further development was not satisfactorily studied. Sometimes the contents of these small sporangia were liberated after one or 
two divisions as non-motile cells. Aplanospores are also formed by the rounding off of the contents of the cells of the disc and branches; when present they occur in large groups.

Systematic Position. This plant does not appear to belong to any known genus of Chaetophoraceae, though it shows close affinity, in some respects, with Chaetonema, Endoclonium, and Pseudochaete. Like these it is apparently one of those many reduced epiphytic forms (Huber, 2) which are closely allied to Stigeocloninm, and of which they have sometimes been considered as species. As regards their epiphytic nature, a few plants only were found growing on Azolla ; the others were on glass, a habitat on which epiphytes very easily develop (Cotton, 1). The relatively large disc and short upright branches are other epiphytic characteristics.

DiAGNosis. The name Trichodiscus elegans is proposed for the plant, and a diagnosis is appended.

\section{Trichodiscus, gen. nov.}

Thallus parvus, epiphyticus, matrici arcte adpressus, discum pseudoparenchymaticum e filamentis radiantibus ramosis inter sese coalitis, ad marginem autem liberis, constitutum efformans, ramis erectis brevibus numerosis et pilis longissimis septatis ornatus; cellulae uninucleatae chromatophoro singulo parietali lobato et pyrenoideo singulo praeditae. Reproductio per zoosporas, per isogametes biciliatas, per aplanosporas, et per cellularum palmelloidearum massulas.

T. elegans, sp. nov.

Characteres ut supra.

$H a b$. ad plantas aquaticas (Azolla) ad Salem in Carolina septentrionali. ${ }^{1}$

Trichodiscus, gen. nov.

Thallus small, epiphytic, closely adpressed to the substratum, and consisting of radiating branched filaments united to form a pseudo-parenchymatous disc with free filaments at the periphery. It bears numerous short erect branches and very long septate hairs. Cells with parietal lobed chloroplast, one nucleus, and one pyrenoid. Reproduction by zoospores, biciliate isogametes, aplanospores, and palmelloid groups.

T. elegans, sp. nov.

Characters of the genus.

Habitat. On Azolla collected at Salem, North Carolina.

Discussion. Many Algae such as Stigeoclonium and Ulothrix have several methods of reproduction, and the occurrence of these has usually been correlated with changes in the environment. Klebs (3) described the variations which are produced by cultivating algae under different conditions. For instance, he records the fact that if plants of Stigeoclonium are grown on an artificial food solution the zoospores are not set free, but

1 My thanks are due to Mr. A. Gepp for help in drawing up the diagnosis. 
germinate in the mother-cell. In Trichodiscus elegans the various phases of reproduction occur simultaneously, and sometimes very close together on the same plant. For instance, one of the figures represents a group of cells in which there is a mature sporangium containing gametes, and close beside it a younger sporangium, which after one division of its contents has ruptured and set free an asexual daughter-cell. Growing close to these is the group shown in another figure, in which there are three young sporangia before division, and one in which the contents, while still within the cellwall, have developed into a thallus. In no case was it found possible to distinguish in any way between those cells which would eventually contain either gametes, asexual daughter-cells, or young plants; the close agreement of their initial cells suggests the possibility that they are homologous structures.

The changes of environment which account for Klebs's results, and which Lang (4) suggests determines whether the sexual or asexual character of a cell is latent or patent, are in this case absent. Here we have both gametes and asexual cells arising under precisely similar conditions. In this case it appears, therefore, that we must look for some stimulus other than the ordinary environmental conditions suggested by Klebs. Such a stimulus is probably closely connected with the nutrition of individual cells, and may be due to some subtle osmotic change acting from within instead of from without, as Livingston (5) has suggested is the case in a species of Stigeoclonium.

\section{SUMmARY.}

I. The alga Trichodiscus elegans, a member of the Chaetophoraceae, is described.

2. In Trichodiscus elegans both sexual and asexual cells were found to be developed from similar initials under the same environmental conditions.

\section{REFERENCE LIST.}

1. Cotton, A. D. : On some Endophytic Algae. Journ. Linn. Soc., vol. xxxvii, I906, p. 293.

2. Huber, G. : Contributions à la connaissance des épiphytes et endophytes et leurs affinités. Ann. Sci. Nat., sér. 7, Bot., vol. xvi, p. $26_{5}$.

3. Klebs, G. : Die Bedingungen der Fortpflanzung bei einigen Algen und Pilzen. Jena, I896.

4. LA NG, W. H.: A Theory of Alternation of Generations in Archegoniate Plants based upon Ontogeny. New Phytologist, vol. viii, I909, p. 5 .

5. Livingston, B. E. : On the Nature of the Stimulus which causes Changes of Form in Polymorphic Green Algae. Bot. Gaz, vol. xxx, I900, p. 289.

The Plate and description of Figures will follow in a subsequent number of THE ANNALS of Botany. The delay is in no way due to the author.-Editorial Note. 


\title{
EXPLANATION OF FIGURES IN PLATE XXVII.
}

\section{(To follow page 242.)}

\author{
Illustrating Miss Welsford's paper on Trichodiscus elegans.
}

Fig. I. Mature plant of Trichodiscus elegans, showing the groups of short erect branches in the centre of the disc and the hairs towards the periphery. $\times 70$.

Fig. 2. Part of periphery of disc, showing the free curving branches and the hairs. $\times 500$.

Fig. 3. A group of short erect branches from the centre of the disc. $\times \mathrm{I}, 000$.

Fig. 4. The lower part of a hair, showing the two basal cells with chloroplasts; the remaining cells contain protoplasm, but no chloroplasts. $\times \mathrm{I}, 000$.

Fig. 5. Part of a young filament, showing branches arising close to the transverse walls. $\times 1,875$.

Fig. 6. Group of large terminal sporangia from centre of disc. The following stages can be seen : one-celled sporangium, two-celled sporangium, eight-celled sporangium, a mature sporangium containing zoospores. $\times \mathrm{r}, 000$.

Fig. 7. A later stage of the same Two empty sporangia and a sporangium from which the zoospores are escaping are shown. $\times 600$.

Fig. 8. A large intercalary sporangium, showing the pores through which four zoospores have already escaped. In the same group two-celled and four-celled sporangia are shown. One of the sporangia after dividing into two has set free one of its daughter cells. $\times$ I,, 000 .

Fig. 9. A zoospore. $\times 1,000$.

Fig. Io. Two zoospores fusing (from fresh material). $\times \mathrm{I}, 000$.

Fig. I I. Resting stage of zygote (from fresh material). $\times$ I,200.

Fig. I2. Three stages in the fusion of the gametes (from material fixed in Flemming's fluid and stained with iron haematoxylin). $\times 1,200$.

Fig. I3. Stages of germination of the zygote. $a$, zygote germinating at one end; $b$, later stage of same; $c$, zygote germinating at both ends; $d$, later stage of same. $\times \mathrm{I}, 200$.

Fig. 14. Part of thallus, showing a young plant developed in a sporangium in situ; four young sporangia before division has taken place are also shown. $\times 750$.

Fig. I5. A seven-celled filamentous plant lying within the wall of the sporangium, which has become separated from the plant. $\times$ I, 000.

Fig. 16. A five-celled filamentous plant which has begun to increase in size but is still surrounded by the sporangium wall, which has become gelatinous. $\times \mathrm{I}, 000$.

Fig. I . A group of small sporangia, showing empty sporangia and also one which still contains four zoospores. $\times \mathrm{I}, 000$.

Fig. 18. A group of aplanospores. $\quad \times \quad 1,000$. 

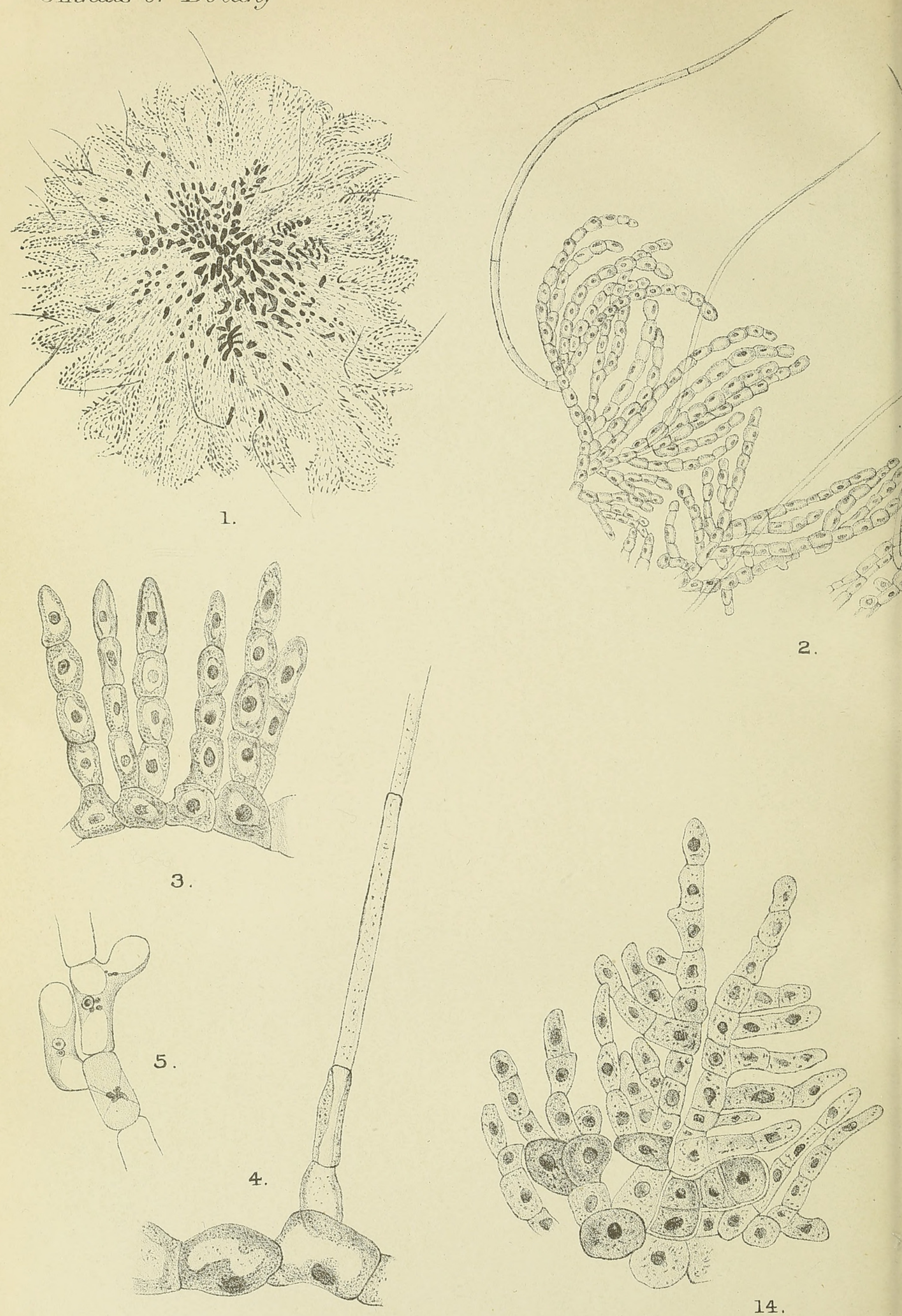

2.

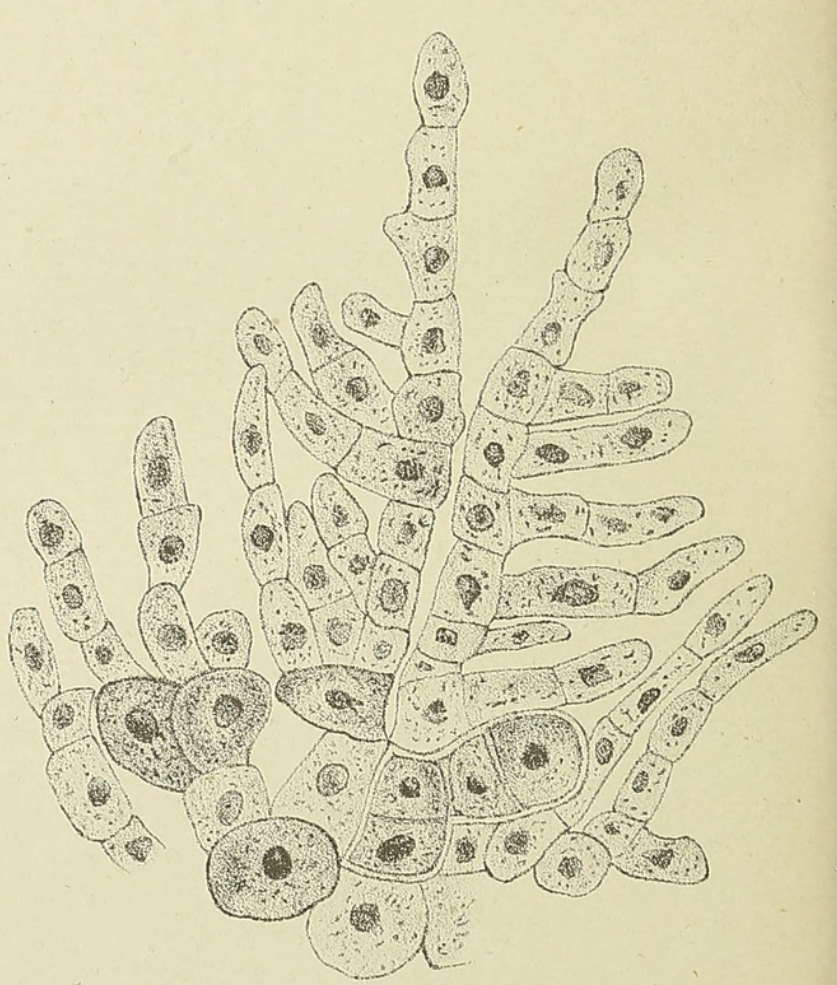

14. 


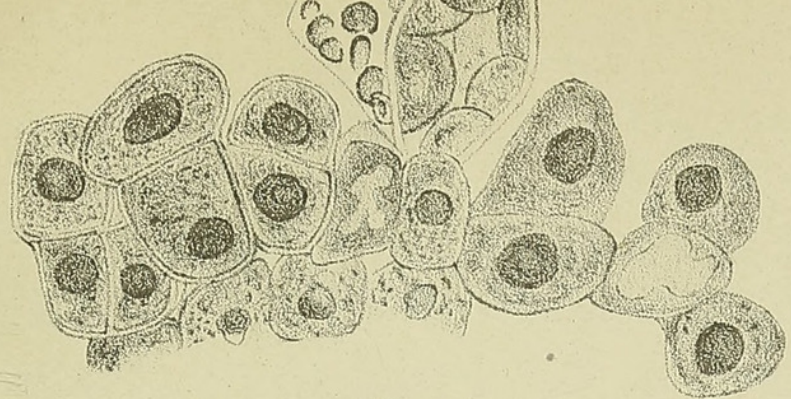

6.

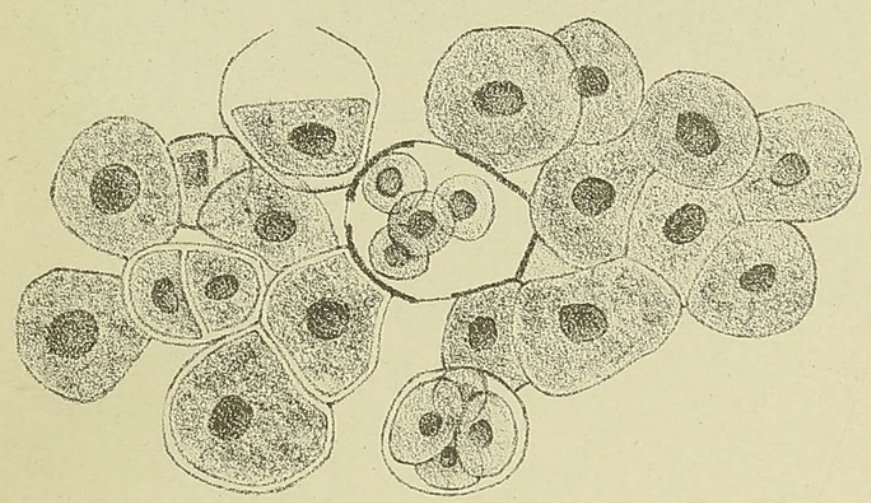

8.

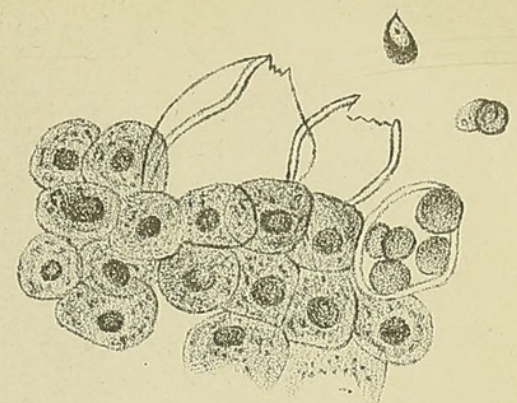

7.

\section{Se
Sen}

a

(1)
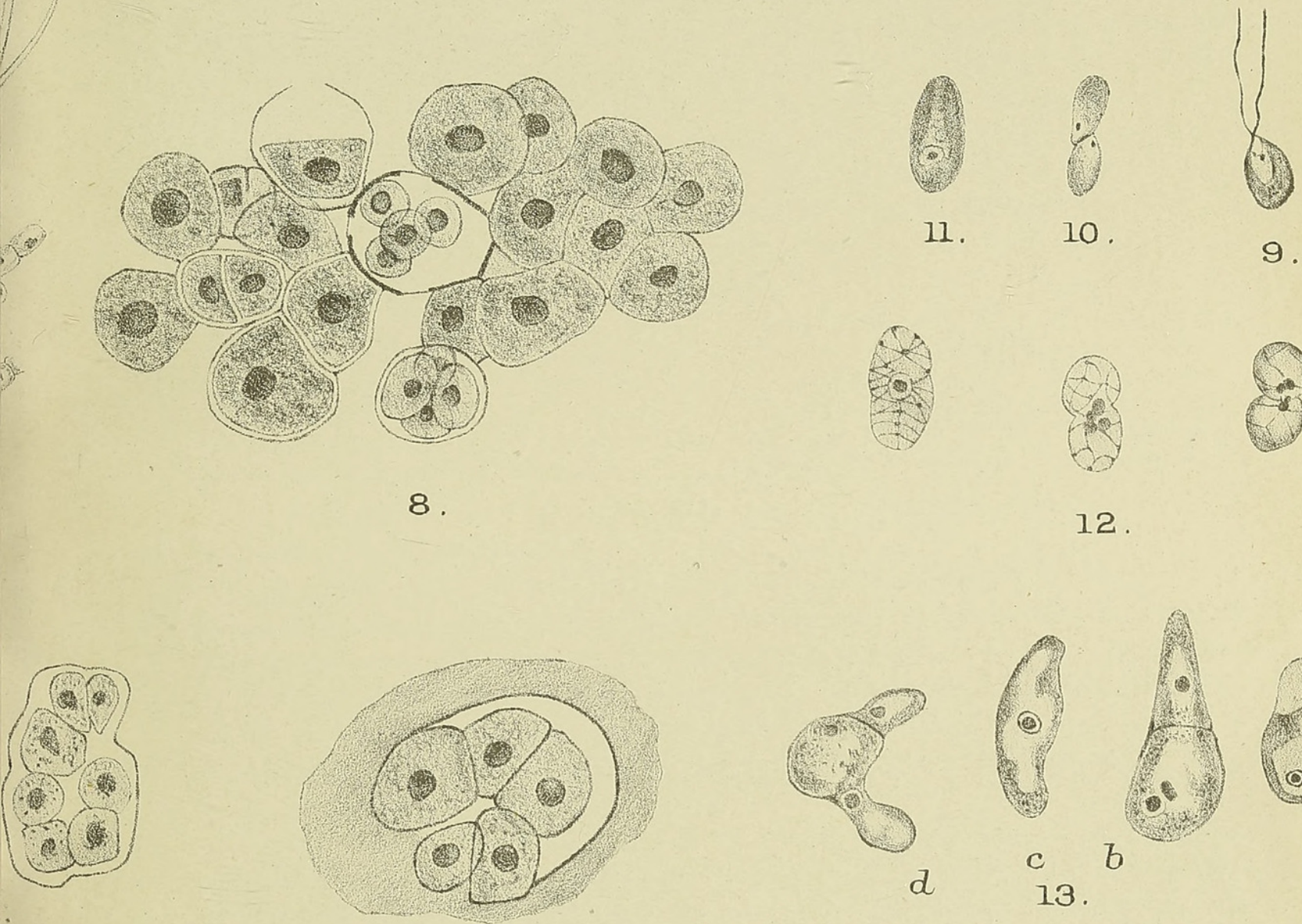

12.

15

16.
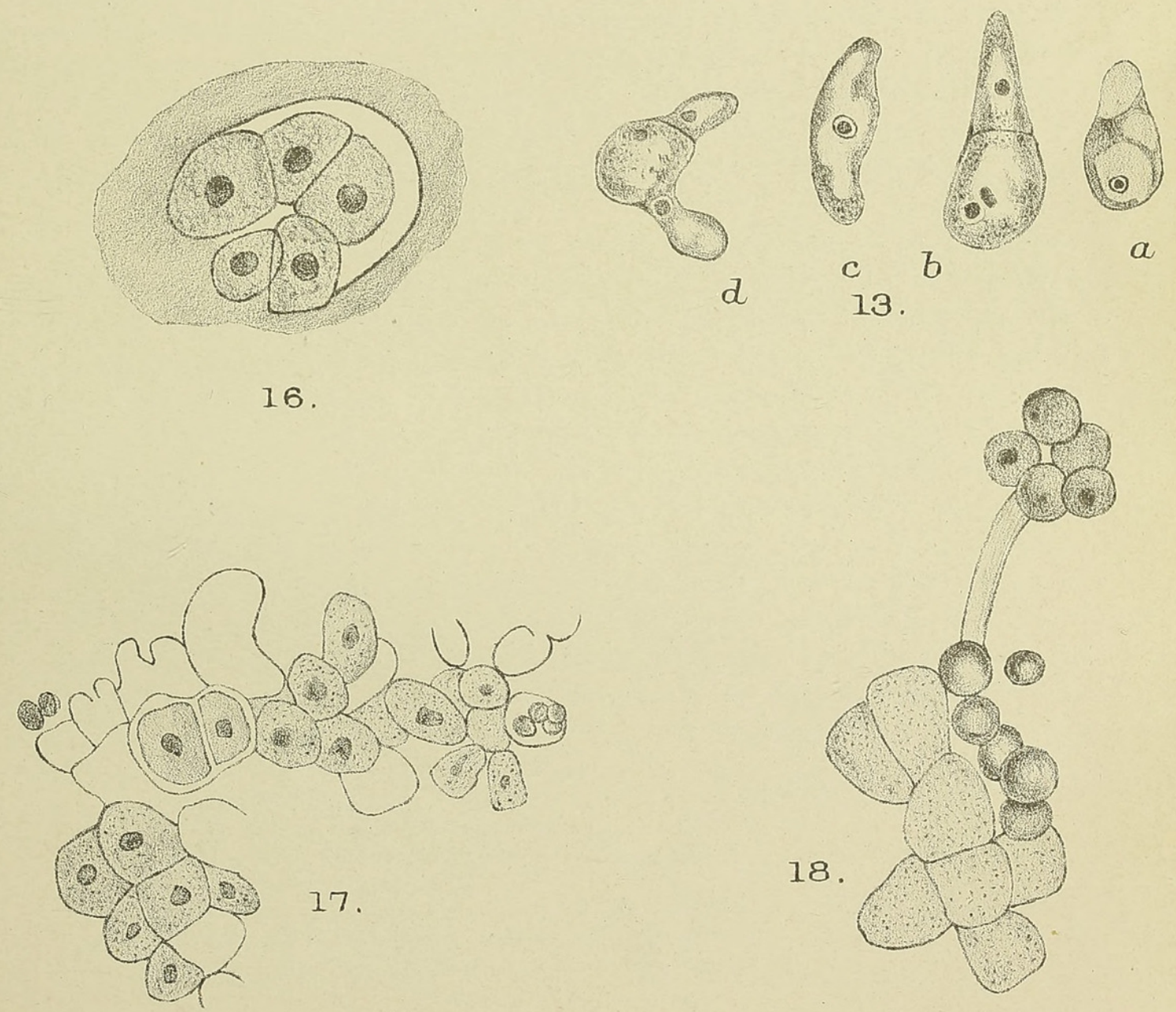

Huth, lith et imp. 


\section{$2 \mathrm{BHL}$ Biodiversity Heritage Library}

Welsford, E. J. 1912. "The morphology of Trichodiscus elegans, gen. et sp. nov." Annals of botany 26, 239-242.

https://doi.org/10.1093/oxfordjournals.aob.a089387.

View This Item Online: https://www.biodiversitylibrary.org/item/236773

DOI: https://doi.org/10.1093/oxfordjournals.aob.a089387

Permalink: https://www.biodiversitylibrary.org/partpdf/319904

\section{Holding Institution}

Smithsonian Libraries

\section{Sponsored by}

Biodiversity Heritage Library

\section{Copyright \& Reuse}

Copyright Status: Not in copyright. The BHL knows of no copyright restrictions on this item.

This document was created from content at the Biodiversity Heritage Library, the world's largest open access digital library for biodiversity literature and archives. Visit BHL at https://www.biodiversitylibrary.org. 